University of Nebraska - Lincoln

DigitalCommons@University of Nebraska - Lincoln

Faculty Publications: Department of

Entomology

Entomology, Department of

1985

Compatibility of Intercropping with Mechanized Agriculture:

Effects of Strip Intercropping of Pinto Beans and Sweet Corn on

Insect Abundance in Colorado

\author{
J. L. Capinera \\ Colorado State University - Fort Collins \\ Thomas J. Weissling \\ University of Nebraska-Lincoln, tweissling2@unl.edu \\ E. E. Schweizer \\ Colorado State University - Fort Collins
}

Follow this and additional works at: https://digitalcommons.unl.edu/entomologyfacpub

Part of the Entomology Commons

Capinera, J. L.; Weissling, Thomas J.; and Schweizer, E. E., "Compatibility of Intercropping with Mechanized Agriculture: Effects of Strip Intercropping of Pinto Beans and Sweet Corn on Insect Abundance in Colorado" (1985). Faculty Publications: Department of Entomology. 322.

https://digitalcommons.unl.edu/entomologyfacpub/322

This Article is brought to you for free and open access by the Entomology, Department of at DigitalCommons@University of Nebraska - Lincoln. It has been accepted for inclusion in Faculty Publications: Department of Entomology by an authorized administrator of DigitalCommons@University of Nebraska - Lincoln. 


\title{
Compatibility of Intercropping with Mechanized Agriculture: Effects of Strip Intercropping of Pinto Beans and Sweet Corn on Insect Abundance in Colorado
}

\author{
J. L. CAPINERA, ${ }^{1}$ T. J. WEISSLING, ${ }^{1}$ AND E. E. SCHWEIZER ${ }^{2}$ \\ Colorado State University, Fort Collins, Colorado 80523
}

\begin{abstract}
J. Econ. Entomol. 78: 354-357 (1985)
ABSTRACT The potential for management of insect pest densities by regulation of crop diversity through intercropping was examined in sweet corn and pinto beans. Insect abundance was monitored in corn and beans in alternating multiple-row patterns of $1,2,4,8$, and 16 rows. Insect responses to intercropping treatments were variable, with positive, negative, and neutral responses observed, depending on species of insect and crop. In some cases, insect abundance was affected by strip-intercropping widths of up to eight rows, suggesting that strip intercropping may be compatible with some types of mechanized agriculture.
\end{abstract}

INTERCROPPING, the simultaneous culture of two or more crops in the same field, is a common cultural practice in tropical countries (Andrews and Kassam 1976, Perrin and Phillips 1978). Intercropping takes various forms, from culture without a distinct row arrangement (mixed intercropping), to alternate single-row patterns (row intercropping) and alternate multiple-row patterns (strip intercropping). Crops may be grown at the same time, or may overlap slightly; in relay intercropping a second crop is planted after the first crop has reached its reproductive stage, but before harvest.

There are many benefits to be derived from intercropping, including reduction in insect pest abundance on crop plants. In a recent review of diversity in agroecosystems, Risch et al. (1983) reported that $53 \%$ of the herbivore species studied exhibited population decreases in diverse cropping patterns, while $18 \%$ were more abundant in diversified systems, and 9\% were unaffected. Agricultural diversification through intercropping tends to be restricted to less developed countries, presumably because this cropping system is not economically feasible in mechanized, North American-style agriculture. However, such high-value, labor-intensive crops as vegetables and fruit may be appropriate systems for intercropping practices (Risch et al. 1983).

Despite a fairly significant effort to document the benefits of intercropping for various crop combinations (e.g., Altieri et al. 1978, Theunissen and Den Ouden 1980, Risch 1980, Risch and Hansen 1982) and crop-weed combinations (e.g., Altieri et al. 1977, 1981, Altieri and Gliessman 1983, Latheef and Ortiz 1983, Barney et al. 1984), and to

\footnotetext{
' Dept. of Entomology.

Dept. of Plant Pathology and Weed Science, and USDA, ARS, Crops Res. Lab.
}

determine the ecological basis for this phenomenon (e.g., Root 1973, Bach 1980, 1981, Risch 1981) many questions remain unanswered. For example, what level of crop diversity (heterogeneity) is necessary for the benefits of intercropping to be obtained? We addressed this question by studying insect abundance in a corn/bean intercropping system with various row- and strip-cropped patterns. Our objective was to determine whether the insect-related benefits of intercropping could be derived from strip-cropped plantings on a scale that was compatible with mechanized agriculture.

\section{Materials and Methods}

A field study was conducted at Fort Collins, Colo., during 1983. Pinto beans ('Olathe') and sweet corn ('Jubilee') were selected as a model intercropping system since bean/corn is a traditional intercropping pattern in the tropics (Pinchinat et al. 1976). Also, their agronomic characteristics in Colorado (planting time, irrigation requirements, maturity, etc.) were compatible. Crops were planted 14 June. A randomized complete block design was used, with six treatments and eight replicates. Treatments consisted of alternate rows of corn and beans in ratios of 1 row beans: 1 row corn (row intercropping), 2:2, 4:4, 8:8 (strip intercropping), and 16 rows of corn or beans. We considered these latter two treatments to be equivalent to monoculture. Plot size was 16 rows by $15.2 \mathrm{~m}$; rows were $0.77 \mathrm{~m}$ apart. Stand density was 18 per $\mathrm{m}$ for beans and 6 per $m$ for corn. The crops were not fertilized. Weeds were controlled chemically with alachlor (Lasso) at $3.4 \mathrm{~kg} / \mathrm{ha}$ applied before planting and with appropriate postplanting mechanical tillage. During the season, the crops were furrowirrigated four times. Soil type was Nunn clay loam with $2.1 \%$ organic matter and $\mathrm{pH} 7.7$.

Insect populations were sampled in all plots at 


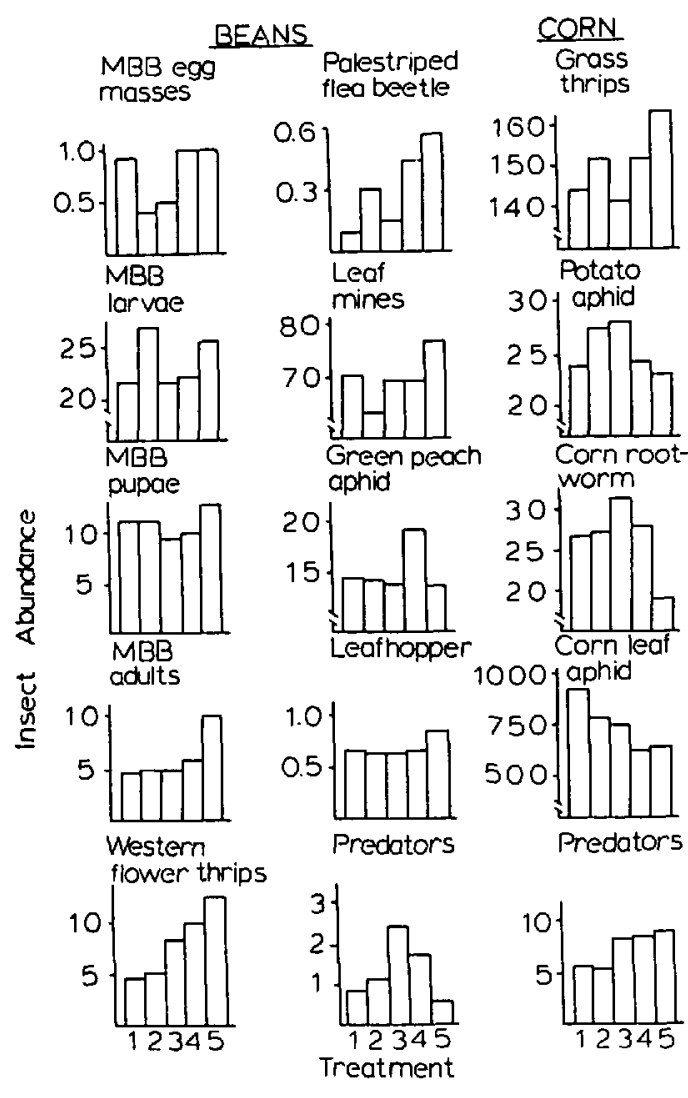

Fig. 1. Abundance of insects on beans and corn in an intercropping study, where treatment 1 is bean/corn strip width of 1 row : 1 row, treatment 2 is $2: 2$, treatment 3 is $4: 4$, treatment 4 is $8: 8$, and treatment 5 is 16 rows of bean or corn. Insect abundance is averaged over four sampling dates except for western flower thrips, where five samples were taken. Abundance is given as no. insects per 25 plants except for western flower thrips, where abundance is no. insects per 25 blossoms. MBB is Mexican bean beetle.

approximately 2-week intervals in mid- and late July and mid- and late August 1983. An additional sampling of beans was conducted 1 week after the mid-August sample (hereafter referred to as sample date $3 b$ ) because of the short life cycle of western flower thrips, Frankliniella occidentalis (Pergande). Insects were sampled from 25 corn and bean plants per plot by visual examination in the four intercropping treatments and the two monoculture treatments. Plants were selected randomly in a transect pattern from plot corner to corner. None of the plants were damaged during the insect sampling procedures except where western flower thrips were sampled in beans. For this sample, a single new opened blossom per plant was torn apart and examined carefully for thrips.

Corn yield was assessed at maturity (20 Aug.) by randomly selecting 100 ears from each plot and examining them for insects and insect-related damage, and by determining wet weight. Insect- related damage was rated visually on a scale ( 1 4) for silk and kernel damage, and for seed set, where a rating of 1 represented undamaged corn or complete seed set, respectively.

Bean yield was assessed by harvesting the center $3 \mathrm{~m}$ from each of eight rows per plot on $10 \mathrm{Sep}-$ tember. Pods, foliage, and debris were removed, and air-dried seed weight determined.

Data were analyzed by analysis of covariance and linear regression. Count values were transformed to square root for analysis. Significant means were separated with Duncan's (1955) new multiple range test at $\alpha=0.05$. Leafhopper species could not be accurately separated in the field, so these data were pooled for analysis. Similarly, several predatory species occurred in low numbers, so they were grouped into a single category. Covariance was used because soil compaction affected plant growth in one row of plots on the edge of the experimental area. The analysis of covariance allowed partial adjustment for this extraneous variation. Data were analyzed separately for each date and crop.

\section{Results and Discussion}

A number of insects were significantly affected by intercropping. Patterns of insect abundance for some important species, averaged over sampling dates, are shown in Fig. 1.

In beans, the Mexican bean beetle, Epilachna varivestris Mulsant, was strongly influenced by bean/corn diversity, with adults generally demonstrating a preference for beans in more homogeneous, or 16-row, plots on both the first sampling date (overwintered beetles) and fourth sampling date (summer beetles) (Table 1). Larvae exhibited a similar distribution on the second sampling date. Leafhopper species apparently were slightly more abundant on beans in monoculture plots on the last date, although the low levels are probably of little biological significance. A positive response to plant homogeneity was shown by western flower thrips, although only the 16-row, monoculture plots had significantly more thrips on the second (3b) thrips sampling date.

In corn, adult western corn rootworms, Diabrotica virgifera LeConte, and corn leaf aphids, Rhopalosiphum maidis (Fitch), were significantly more abundant in the heterogeneous (narrow width) plots on the third sampling date. In contrast, palestriped flea beetles, Systena blanda Melsheimer, and Phalacrus sp., a shining flower beetle, were more abundant on homogeneous plots during the early sampling periods.

Several species did not respond significantly to intercropping patterns. Grass thrips, Anaphothrips obscurus (Müller), potato aphids, Macrosiphum euphorbiae (Thomas), greenbugs, Schizaphis graminum (Rondani), spider mites (two spotted spider mite, Tetranychus urticae Koch, and Banks grass mite, Oligonychus pratensis [Banks]) oc- 
Table 1. Abundance of insect species (no. per 25 plants) that exhibited significant responses to intercropping ${ }^{a}$

\begin{tabular}{|c|c|c|c|c|c|c|c|}
\hline \multirow{2}{*}{ Crop } & \multirow{2}{*}{ Date } & \multirow{2}{*}{ Insect } & \multicolumn{5}{|c|}{ Treatment } \\
\hline & & & 1 & 2 & 3 & 4 & 5 \\
\hline \multirow[t]{5}{*}{$\overline{\text { Corn }}$} & 1 & Phalacrus sp. & $0 \mathbf{a}$ & $0 \mathbf{a}$ & $0 \mathrm{a}$ & $0.25 \mathrm{ab}$ & $0.37 \mathrm{~b}$ \\
\hline & 2 & $\begin{array}{l}\text { Palestriped } \\
\text { Glea beetle }\end{array}$ & $0 \mathbf{a}$ & $0 \mathbf{a}$ & $\mathrm{Oa}$ & $\mathrm{Oa}$ & $0.25 b$ \\
\hline & 3 & $\begin{array}{l}\text { Western corn } \\
\text { rootworm }\end{array}$ & $4.92 b$ & $4.34 b$ & $5.65 b$ & $4.11 \mathrm{ab}$ & $1.96 \mathrm{a}$ \\
\hline & & Corn leaf aphid & $3,502 \mathrm{~b}$ & $2,864 a b$ & $2,772 \mathrm{ab}$ & $2,279 a$ & $2,365 a$ \\
\hline & 4 & None & & & & & \\
\hline \multirow[t]{6}{*}{ Bean } & 1 & $\begin{array}{l}\text { Mexican bean } \\
\text { beetle adults }\end{array}$ & $1.00 \mathrm{ab}$ & $1.12 \mathrm{ab}$ & $0.25 b$ & $1.12 \mathrm{ab}$ & $2.00 \mathrm{a}$ \\
\hline & 2 & $\begin{array}{c}\text { Mexican bean } \\
\text { beetle larvae }\end{array}$ & $12.23 \mathrm{ab}$ & $8.37 b$ & $14.62 \mathrm{ab}$ & $16.87 \mathrm{ab}$ & $18.87 \mathrm{a}$ \\
\hline & $3 \mathbf{a}$ & None & & & & & \\
\hline & $3 b$ & $\begin{array}{l}\text { Western flower } \\
\text { thrips }\end{array}$ & $15.25 \mathrm{a}$ & $15.87 \mathrm{a}$ & $21.75 a$ & $24.12 \mathrm{a}$ & $36.62 b$ \\
\hline & 4 & $\begin{array}{l}\text { Mexican bean } \\
\text { beetle adults }\end{array}$ & $16.50 \mathrm{a}$ & $16.37 \mathrm{a}$ & $17.87 \mathrm{ab}$ & $20.00 \mathrm{ab}$ & $35.87 \mathrm{~b}$ \\
\hline & & Leafhopper spp. & $0 \mathrm{a}$ & $0 \mathbf{a}$ & $0 \mathrm{a}$ & $0 \mathrm{a}$ & $0.25 b$ \\
\hline
\end{tabular}

Means within rows followed by the same letter are not significantly different ( $P<0.05$; Duncan's [1955] new multiple range test).

a Data from species that did not demonstrate statistically significant differences are not presented. See text for dates, and Fig. 1 legend for treatments.

curred on corn foliage. Green peach aphids, $M y$ zus persicae (Sulzer), bean aphids, Aphis fabae Scopoli, pea aphids, Acyrthosiphum pisum (Harris), and vegetable leafminers, Liriomyza sativae Blanchard, occurred on beans. Predators commonly occurring on both corn and bean foliage included common green lacewings, Chrysopa carnea Stephens, convergent lady beetles, Hippodamia convergens Guerin-Meneville, and minute pirate bugs, Orius tristicolor (White). When corn ears were sampled at maturity, larvae of European corn borers, Ostrinia nubilalis (Hübner), corn earworms, Heliothis zea (Boddie), and western bean cutworms, Loxagrotis albicosta (Smith), were found at low levels of abundance, with only 0.05 , 1.64 , and $1.41 \%$ of the corn ears infested, respectively.

Intercropping patterns had pronounced effects on corn and bean yield, with bean yield positively correlated, and corn yield negatively correlated, with crop homogeneity (Fig. 2). This pattern commonly results when crops of dissimilar height compete for light (Trenbath 1976). Optimal crop ratios can be calculated using the "relative yield total" technique (Trenbath 1976), but the crop varieties selected for this study were not adapted for intercropping, which precludes realistic assessment. Insect damage to corn ears did not differ significantly among treatments.

The observed insect responses are consistent with those of previous studies. Some species (e.g., Mexican bean beetle, western flower thrips) were favored by, or attracted to, homogeneous plots, while several species were unaffected by intercropping, and two species (western corn rootworm and corn leaf aphid) apparently were favored by heterogeneity. Thus, abundance of important crop pests was decreased in beans, but increased in corn, by bean/corn intercropping. The significance of the studies, however, is related not to whether positive or negative effects occurred, but where they occurred on the continuum of crop heterogeneity/ homogeneity.

The abundance of corn- and bean-feeding insects was shown to be amenable to manipulation by strip intercropping, and in several cases the insect densities did not differ significantly among one-, two-, four-, and eight-row "strips," but were significantly different from 16-row "monocultures." Therefore, the benefits of tropical inter-

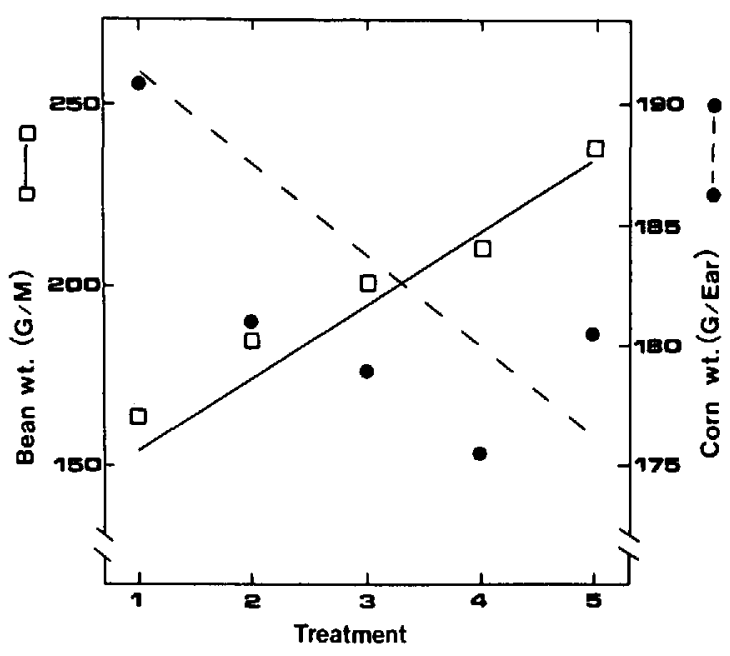

Fig. 2. Yield of dry beans ( $\mathrm{g} /$ row-m) and sweet corn (g wet wt per ear) from intercropping plots; see Fig, 1 legend for treatment descriptions. Regression equation for beans is $Y=147.37+17.03 X(r=0.987)$; equation for corn is $Y=190.40-2.80 \mathrm{X}(r=-0.732)$. 
cropping systems related to insect management also may be obtained in mechanized cropping systems where multiple-row planting and harvesting is practical. Other intercropping systems using crop varieties adapted for competition, or crops with more uniform height, may be more practical than the model system studied herein. As suggested by Risch et al. (1983), intercropping may be more appropriate for vegetable and fruit crops than for field crops. However, where benefits other than pest management can be derived from intercropping (e.g., wind protection [Radke and Hagstrom 1976]), even field crops or crops with different heights should be considered as candidate systems.

\section{Acknowledgment}

This research was supported by USDA, ARS and Colorado Agric. Exp. Stn. The assistance of C. Taylor and P. Chapman, CSU Statistics Laboratory, is gratefully acknowledged.

\section{References Cited}

Altieri, M. A., and S. R. Gliessman. 1983. Effects of plant diversity on the herbivory of the flea beetle, Phyllotreta cruciferae Goeze, in California collard (Brassica oleraceae) cropping systems. Crop Prot. 2: 497-501.

Altieri, M. A., A. van Schoonhoven, and J. Doll. 1977. The ecological role of weeds in insect pest management systems: a review illustrated by bean (Phaseolus vulgaris) cropping systems. PANS (Pest Artic. News Summ.) 23: 195-205.

Altieri, M. A., C. A. Francis, A. van Schoonhoven, and J. D. Doll. 1978. A review of insect prevalence in maize (Zea mays L.) and bean (Phaseolus vulgaris L.) polycultural systems. Field Crops Res. 1: 33-49.

Altieri, M. A., J. W. Todd, E. W. Hauser, M. Patterson, G. A. Buchanan, and R. H. Walker. 1981. Some effects of weed management and row spacing on insect abundance in soybean fields. Prot. Ecol. 3: 339343.

Andrews, D. L., and A. H. Kassam. 1976. The importance of multiple cropping in increasing world food supplies, pp. 1-10. In R. I. Papendick, P. A. Sanchez, and G. B. Triplett [eds.], Multiple cropping. American Society of Agronomy, Madison, Wisc.

Bach, C. E. 1980. Effects of plant diversity and time of colonization on an herbivore-plant interaction. Oecologia 44: 419-426.

1981. Host plant growth form and diversity: effects on abundance and feeding preference of a specialist herbivore, Acalymma vittata (Coleoptera: Chrysomelidae). Ibid. 50: 370-375.

Barney, R. J., W. O. Lamp, E. J. Armbrust, and G. Kapusta. 1984. Insect predator community and its response to weed management in spring-planted alfalfa. Prot. Ecol. 6: 23-33.

Duncan, D. B. 1955. Multiple range and multiple $F$ tests. Biometrics 11: 1-42.

Latheef, M. A., and J. H. Ortiz. 1983. The influence of companion herbs on egg distribution of the imported cabbageworm, Pieris rapae (Lepidoptera: Pieridae), on collard plants. Can. Entomol. 115: 10311038.

Perrin, R. M., and M. L. Phillips. 1978. Some effects of mixed cropping on the population dynamics of insect pests. Entomol. Exp. Appl, 24: 385-393.

Pinchinat, A. M., J. Soria, and R. Bazan. 1976. Multiple cropping in tropical America, pp. 51-61. In R. I. Papendick, P. A. Sanchez, and G. B. Triplett [eds.], Multiple cropping. American Society of Agronomy, Madison, Wisc.

Radke, J. K., and K. T. Hagstrom. 1976. Strip intercropping for wind protection, pp. 201-222. Ibid.

Risch, S. J. 1980. The population dynamics of several herbivorous beetles in a tropical agroecosystem: the effect of intercropping corn, beans and squash in Costa Rica. J. Appl. Ecol. 17: 593-612.

1981. Insect herbivore abundance in tropical monocultures and polycultures: an experimental test of two hypotheses. Ecology 62: 1325-1340.

Risch, S. J., and M. K. Hansen. 1982. Plant growth, flowering phenologies, and yields of corn, bean and squash grown in pure stands and mixtures in Costa Rica. J. Appl. Ecol. 19: 901-916.

Risch, S. J., D. Andow, and M. A. Altieri. 1983. Agroecosystem diversity and pest control: data, tentative conclusions, and new research directions. Environ. Entomol. 12: 625-629.

Root, R. B. 1973. Organization of a plant-arthropod association in simple and diverse habitats: the fauna of collards (Brassica oleraceae). Ecol. Monogr. 43: 95-124.

Theunissen, J., and H. Den Ouden. 1980. Effects of intercropping with Spergula arvensis on pests of brussels sprouts. Entomol. Exp. Appl. 27: 260-268.

Trenbath, B. R. 1976. Plant interactions in mixed crop communities, pp. 129-169. In R. I. Papendick, P. A. Sanchez, and G. B. Triplett [eds.], Multiple cropping. American Society of Agronomy, Madison, Wisc.

Received for publication 20 July 1984; accepted 9 November 1984. 